\title{
EDUKASI KESEHATAN MASYARAKAT DAN KETAHANAN PANGAN UNTUK MENGHADAPI WABAH COVID-19 DI DESA NGRINGO KECAMATAN JATEN KABUPATEN KARANGANYAR
}

\author{
Adi Ratriyanto ${ }^{1}$, Elisa Herawati ${ }^{2}$ dan Nanda Putri Pertiwi ${ }^{3}$ \\ ${ }^{1}$ Program Studi Peternakan, Fakultas Pertanian, Universitas Sebelas Maret, Surakarta \\ ${ }^{2}$ Program Studi Biologi, Fakultas Matematika dan Ilmu Pengetahuan Alam, Universitas Sebelas Maret, Surakarta \\ ${ }^{3}$ Mahasiswa Pendidikan Kimia, Fakultas Keguruan dan Ilmu Pendidikan, Universitas Sebelas Maret, Surakarta \\ E-mail: ratriyanto@staff.uns.ac.id
}

\begin{abstract}
Abstrak
Wabah coronavirus disease 2019 (Covid-19) yang disebabkan oleh Severe Acute Respiratory Syndrome Coronavirus-2 (SARS-COV-2) pertama dilaporkan di Indonesia pada bulan Maret 2020, diikuti dengan peningkatan jumlah penderita wabah. Masih rendahnya kesadaran masyarakat untuk mentaati protokol kesehatan menyebabkan penyebaran virus ini sulit dihentikan. Oleh karena itu Universitas Sebelas Maret menggerakkan mahasiswa untuk melakukan Kuliah Kerja Nyata (KKN) Tematik Covid-19 di domisili masing-masing mahasiswa. Kegiatan KKN ini bertujuan mengedukasi masyarakat mengenai protokol kesehatan agar masyarakat semakin sadar dan mengerti bahaya Covid-19. KKN Covid-19 ini dilaksanakan di Desa Ngringo Kecamatan Jaten Kabupaten Karanganyar. Program yang dilakukan secara luring adalah pembagian dan edukasi pembuatan masker, pembuatan handsanitizer, ketahanan pangan, Chemistry Class, penyemprotan desinfektan, pendataan pemudik, edukasi cuci tangan dan beberapa kegiatan daring seperti pembagian informasi melalui sosial media. Peran nyata mahasiswa sangat dibutuhkan dalam rangka pemutusan mata rantai penyebaran Covid-19 ini sehingga dengan adanya KKN mampu memberikan dampak positif bagi masyarakat sekitar. Masyarakat sekitar menjadi paham akan pentingnya physical/social distancing, pentingnya stay at home, mencuci tangan, Pola Hidup Bersih dan Sehat (PHBS), dan memakai masker ketika keluar rumah sesuai dengan protokol kesehatan. Adanya kegiatan penanaman sayuran dan pemeliharaan lele di pekarangan dapat meningkatkan ketahanan pangan keluarga di era Covid-19.
\end{abstract}

Kata Kunci : Covid-19, physical/social distancing, stay at home, protokol kesehatan, ketahanan pangan

\section{PENDAHULUAN}

Pada awal 2020, dunia dikejutkan dengan mewabahnya pneumonia baru yang diberi nama coronavirus disease 2019 (Covid-19) yang disebabkan oleh Severe Acute Respiratory Syndrome Coronavirus-2 (SARS-CoV-2). Covid-19 pertama dilaporkan di Indonesia pada bulan Maret 2020 (www.covid19.go.id; Wulandari et al., 2020).
Coronavirus adalah virus RNA dengan ukuran partikel 120-160 nm. Virus ini dapat ditularkan dari manusia ke manusia dan telah menyebar secara luas. Hasil analisis filogenetik menunjukkan bahwa virus ini masuk dalam subgenus yang sama dengan coronavirus yang menyebabkan wabah Severe Acute Respiratory Illness (SARS) pada 2002-2004,

Kesehatan 
yaitu Sarbecovirus. Penyebaran penyakit ini telah memberikan dampak luas secara sosial dan ekonomi (Susilo et al., 2020). Pandemi ini membawa dampak yang besar bagi kehidupan masyarakat. Tak hanya menyebabkan permasalahan ekonomi tetapi juga berpotensi pada krisis kebutuhan pangan dan Pendidikan (Nurkholis, 2020).

Masih rendahnya kesadaran masyarakat untuk mentaati protokol kesehatan menyebabkan penyebaran virus ini menjadi sangat cepat dan sulit dihentikan. Pada warga masyarakat desa Ngringo, Kecamatan Jaten, Kabupaten Karanganyar terdapat beberapa titik dimana aktivitas masih terlihat normal tidak adanya physical distancing seperti yang diarahkan oleh world health organization (WHO) yaitu tindakan jarak sosial dan fisik bertujuan untuk memperlambat penyebaran penyakit dengan menghentikan rantai penularan Covid-19. Diperlukan kesadaran kolektif dan disiplin masyarakat untuk mentati protokol kesehatan yang agar segera bisa mengakhiri wabah ini. Oleh karena itu perlu dilakukan edukasi kepada masyarakat mengenai protokol kesehatan secara kontinu agar kesadaran masyarakat semakin muncul. Hal ini dapat dilakukan dengan menyebar poster maupun broadcast mengenai protokol kesehatan yang dianjurkan pemerintah.

Mahasiswa Universitas Sebelas Maret (UNS) diharapkan dapat memberikan kontribusi nyata untuk membantu masyarakat tanggap Covid19 melalui program KKN Tanggap Wabah Covid19. Adanya KKN UNS ini diharapkan dapat mengedukasi masyarakat akan Covid-19 dan pencegahan dengan menerapkan protokol kesehatan serta membantu pendidikan anak- anak dengan adanya pembelajaran online karena sebagian anak memerlukan pendampingan belajar dan mengenalkan kepada masyarakat tentang ketahanan pangan serta hidroponik. Tujuan kegiatan untuk mengedukasi masyarakat mengenai protokol kesehatan agar masyarakat semakin sadar dan mengerti bahaya Covid-19.

\section{METODE}

Kegiatan ini merupakan kegiatan KKN Covid-19 dilaksanakan di Desa Ngringo Kecamatan Jaten, Kabupaten Karanganyar pada bulan Mei 2020. Pelaksana kegiatan di lapangan adalah Nanda
Putri Pertiwi, mahasiswa Pendidikan Kimia FKIP UNS. Kegiatan KKN dilaksanakan dalam 2 bentuk yaitu kegiatan secara luring dan kegiatan secara daring.

Kegiatan luring dilakukan langsung dengan terjun ke lapangan, meliputi pemberian informasi mengenai Covid-19 dengan menggunakan media cetak yaitu berupa poster dan MMT di tempattempat strategis, pembuatan dan pembagian hand sanitizer kepada masyarakat, penyeprotan desinfektan, pembuatan dan pembagian masker, edukasi cuci tangan kepada anak-anak, dan lomba Dusun Siaga Covid-19. Pembuatan hand sanitizer dilakukan di Laboratorium Kimia FKIP UNS. Selain itu juga dilakukan program ketahanan pangan, yaitu dengan menanam sayuran di lahan pekarangan dan pemeliharaan lele.

Kegiatan secara daring dilakukan melalui media sosial seperti WhatsApp (WA), Instagram dan Youtube. Kegiatan daring meliputi penyebaran informasi mengenai Covid-19 melalui instagram dan WA, penyebaran informasi berupa video tutorial melalui Youtube, dan kegiatan pembelajaran online Chemistry Class untuk anak SMA.

\section{HASIL DAN PEMBAHASAN}

\section{Penyebaran Informasi COVID-19}

Pengetahuan masyarakat tentang Covid-19 dan pencegahannya berkisar antara 64-77\% dengan kategori baik, sedang sisanya memiliki pengetahuan yang kurang baik terhadap Covid-19 (Wulandari et al., 2020). Tingginya kesenjangan pengetahuan terhadap penyakit, memerlukan upaya penanggulangan untuk mencegah penyebaran yang meluas (Susilo, et al. 2019). Oleh karena itu masih diperlukan penyebaran informasi mengenaik Covid19 kepada masyarakat. Penyebaran informasi mengenai Covid-19 dilakukan secara daring dan luring.

Kegiatan luring dilakukan dengan pemasangan MMT dan poster untuk menyebarkan informasi mengenai Covid-19. Kegiatan pemasangan MMT dan poster dilakukan untuk memberikan informasi kesemua warga ditempat umum ataupun di tempat-tempat strategis (Gambar 
1). Diharapkan dengan pemasangan MMT dan poster yang berisi himbuan warga masyarakat lebih memahami apa itu virus corona, bagaimana gejalanya, protokol kesehatan dan apa yang harus dilakukan ketika beraktivitas di luar rumah, sehingga warga masyarakat akan lebih berhati-hati. Melalui pemasangan MMT dan poster, warga Desa Ngringo menjadi paham dan dapat memutus mata rantai penyebaran virus Covid-19. Pelaksanaan program ini MMT dipasang ditempat strategis yaitu di terminal palur dan balai desa Ngringo yang dapat dibaca oleh semua orang. Poster yang berisi informasi dipasang di Posko Covid-19 desa Ngringo, Puskesmas, Terminal, Halte Bus, Pos Ronda, dan diperempatan dusun Serut RT 06 RW 12, sehingga semua warga sekitar akan mendapatkan infromasi dari sumber yang terpercaya.
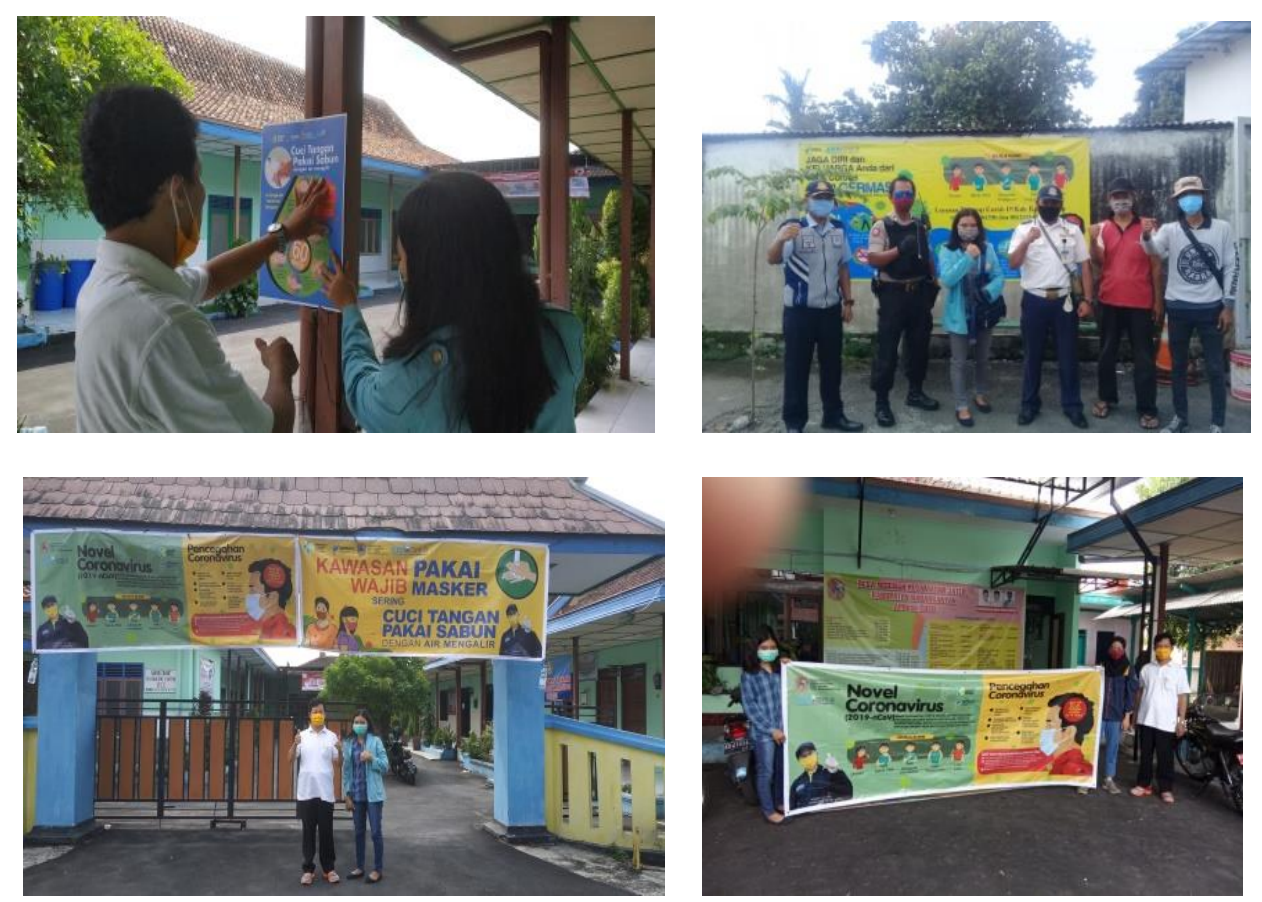

Gambar 1. Penempelan poster dan MMT dilokasi strategis di Desa Ngringo

Kegiatan penyebaran informasi mengenai Covid-19 secara daring dilakukan melalui sosial media instagram dan youtube dan grup WA. Informasi yang diberikan melalui instagaram merupakan kegiatan bersama dengan relawan online corona UNS yang disebarkan melalui instagram pribadi (Gambar 2). Dengan dilakukan penyebaran informasi secara pribadi maka akan banyak orang yang paham dan tau apa yang perlu dilakukan agar tidak terkena virus Covid-19 ini dan menerapkan protokol kesehatan yang ada. Kegiatan daring juga disebarkan melalui instagram khusus KKN yaitu 'marilawancorona' yang menyebarkan informasi apa itu Covid-19.

\section{Edukasi Cuci Tangan}

Edukasi cuci tangan dilakukan dengan door to door yang dilakukan dengan mendatangi rumahrumah untuk mengedukasi cuci tangan kepada anak-anak (Gambar 3). Kegiatan bertujuan untuk memberi edukasi kepada anak-anak akan pentingnya cuci tangan untuk hidup sehat. Mengajak anak-anak untuk menjaga kebersihan dan kesehatan dengan menucuci tangan dengan langkah-langkah yang benar. Dengan adanya program ini anak-anak dapat mengetahui langkah cuci tangan dengan sabun yang benar. Sehingga dengan adanya program edukasi cuci tangan dapat memutuskan mata rantai penyebaran Covid-19. 

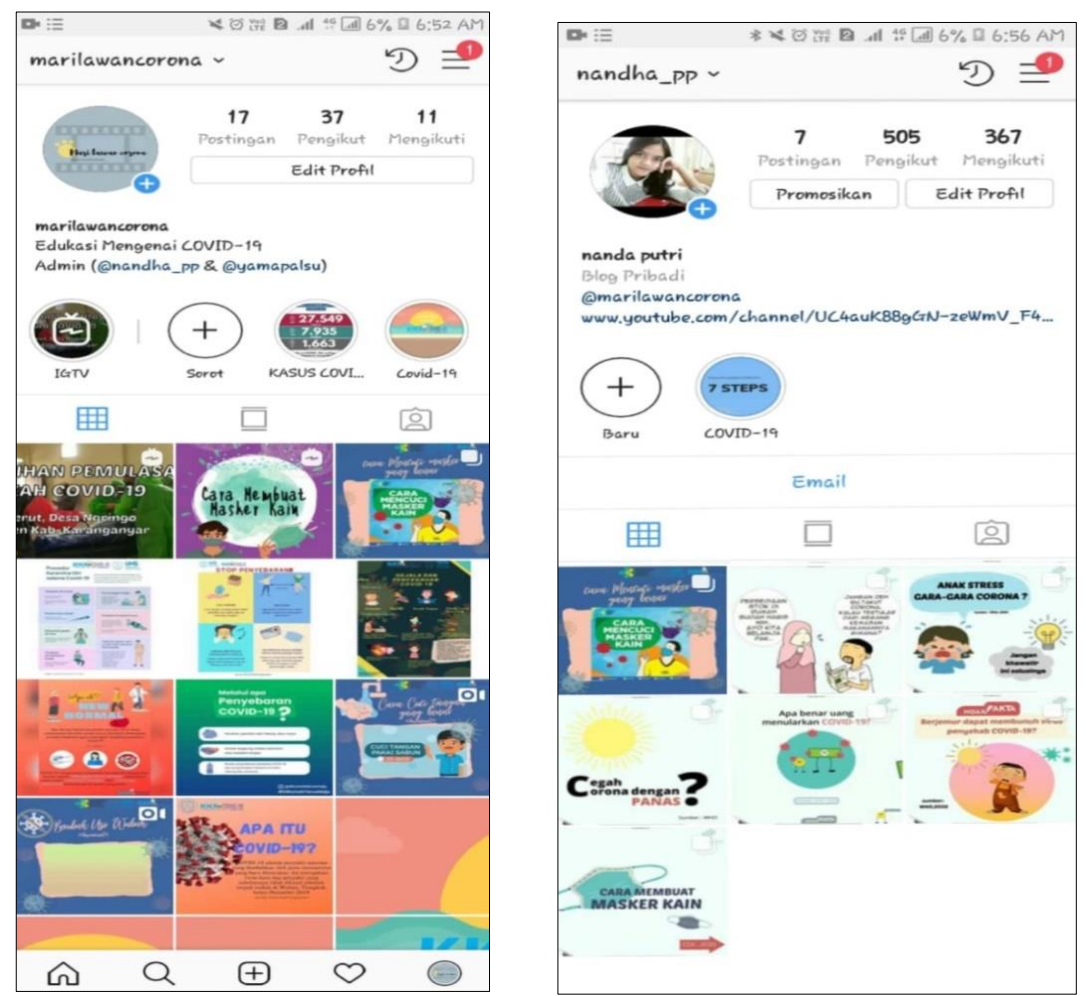

Gambar 2. Penyebaran informasi melalui sosial media instagram

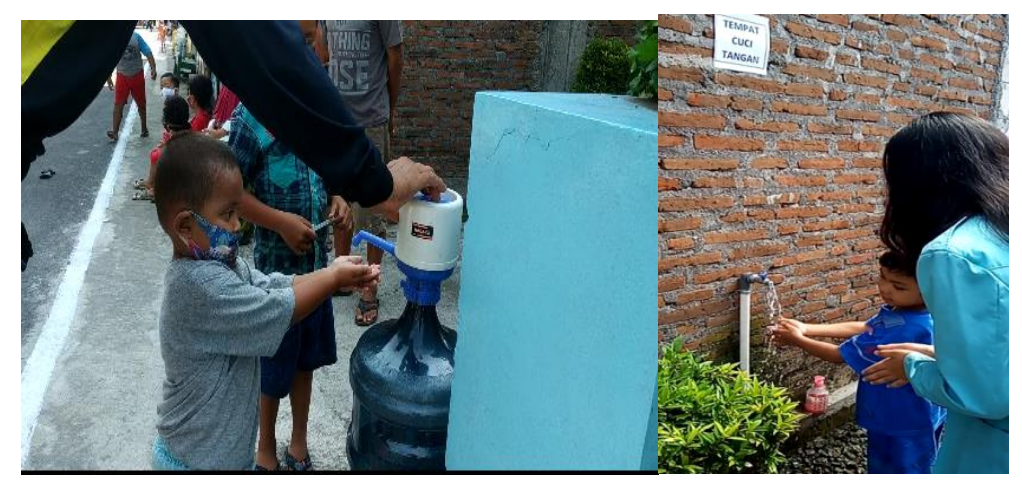

Gambar 3. Edukasi Cuci tangan untuk kepada anak-anak

\section{Pembuatan Hand sanitizer}

Pembuatan handsanitizer merupakan salah satu program kerja dari KKN yang dilakukan di Desa Ngringo ini sebagai tujuan pemutusan mata rantai penyebaran covid-19 (Gambar 4). Selain itu, dapat mendorong masyarakat untuk hidup bersih dan sehat dengan menggunakan hand sanitizer ketika bepergian keluar rumah atau apabila tidak bisa cuci tangan secara langsung. Pembuatan hand sanitizer dilakukan sesuai dengan anjuran WHO dengan menggunakan alkohol, gliserin dan $\mathrm{H}_{2} \mathrm{O}_{2}$. Hand sanitizer dibuat dalam kemasan besar dan kecil yang kemudian diberi label serta logo UNS dan KKN dengan ukuran $50 \mathrm{ml}$ dan $250 \mathrm{ml}$ (Gambar 5). Kemudian setelah proses pengemasan dilakukan distribusi hand sanitizer kepada warga masyarakat dengan simbolis dilakukan penyerahan kepada Kepala desa Ngringo. Melaui program ini warga yang harus tetap bekerja diluar merasa terbantu dan merasa aman ketika keluar rumah untuk melakukan aktivitas. 


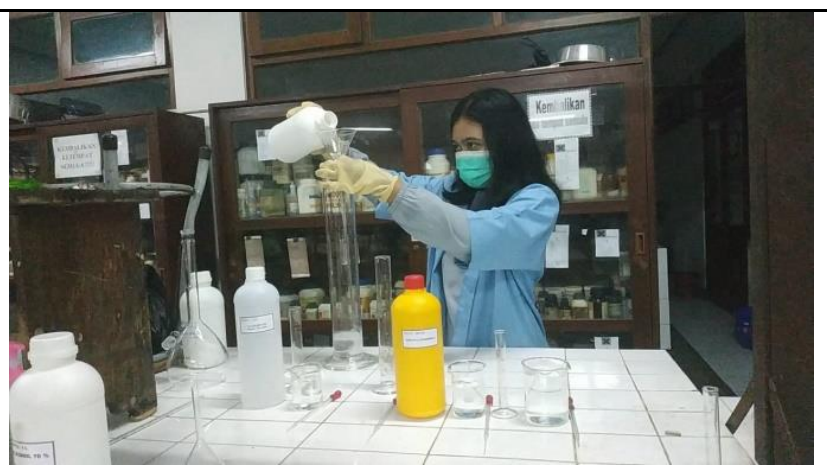

Gambar 4. Pembuatan Handsanitizer di Laboratorium Kimia FKIP UNS
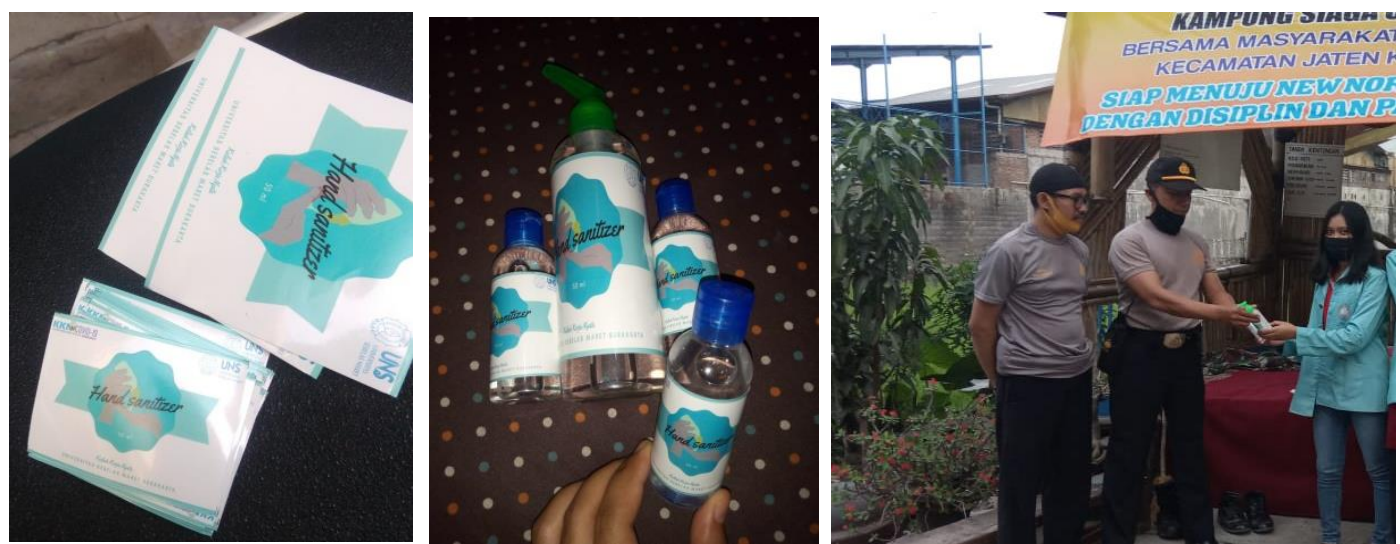

Gambar 5. Pelabelan dan pendistribusian hand znitizer yang sudah dibuat

\section{Gerakan Memakai Masker (GEMAS)}

Program gerakan memakai masker (GEMAS) adalah edukasi pentingnya pemakaian masker ketika beraktivitas diluar rumah, edukasi pemakaian masker yang baik, edukasi cara mencuci masker yang benar menurut kemenkes dan pembuatan video tutorial tata cara pembuatan masker kain sendiri dirumah (Gambar 3). Pembagian video tutorial pembuatan masker dibagikan pada sosial media instagram, youtube dengan link https://www.youtube.com/watch?v=Nzd7PMd99R $\underline{Q}$ dan pada grup WA. Pembagian masker dilakukan ditempat umum dan warga sekitar. Pembagain masker di tempat umum seperti dilakukan di pasar dan dilakukan di terminal. Pembagaian masker di pasar disertai dengan edukasi karena banyaknya pedagang pasar yang berusia lajut dan sangat riskan terhadap virus Covid-19 ini dan tetap beraktivitas sehari-hari. Sehingga dengan adanya pembagian masker di pasar tradisional ini maka pedagang mengetahui pentingnya memakai masker ketika berjualan dan tetap melakukan protokol kesehatan
(Gambar 6). Pembagian masker juga dilakukan di terminal karena banyak orang yang tidak peduli akan pentingnya memakai masker dengan alasan tidak nyaman dan tidak memiliki masker, sehingga dengan dilakukan edukasi dan pembagain masker di terminal mereka mulai sadar pentingnya memakai masker dan melakukan jaga jarak ketika melukan aktivitas. Adanya program GEMAS diharapkan dapat memutus rantai pencebaran Covid-19 karena infeksi penyebaran dari satu orang ke orang lain melalui percikan (droplet) dari saluran pernapasan yang sering dihasilkan saat batuk atau bersin.

\section{Penyemprotan Desinfektan dan Edukasi New Normal serta Protokol Kesehatan}

Program kerja penyemprotan desinfektan dilakukan bersama dengan Babinsa, Bhabinkamtibmas, perangkat desa, BPD dan karang taruna desa yang tergabung dalam SATGAS Covid19 desa Ngringo. Kegiatan penyemprotan desinfektan dilakukan sebanyak 8 Dusun yang dilakukan pada hari Sabtu tanggal 30 Mei 2020 (Gambar 7 dan 8). Kegiatan dilakukan beserta 


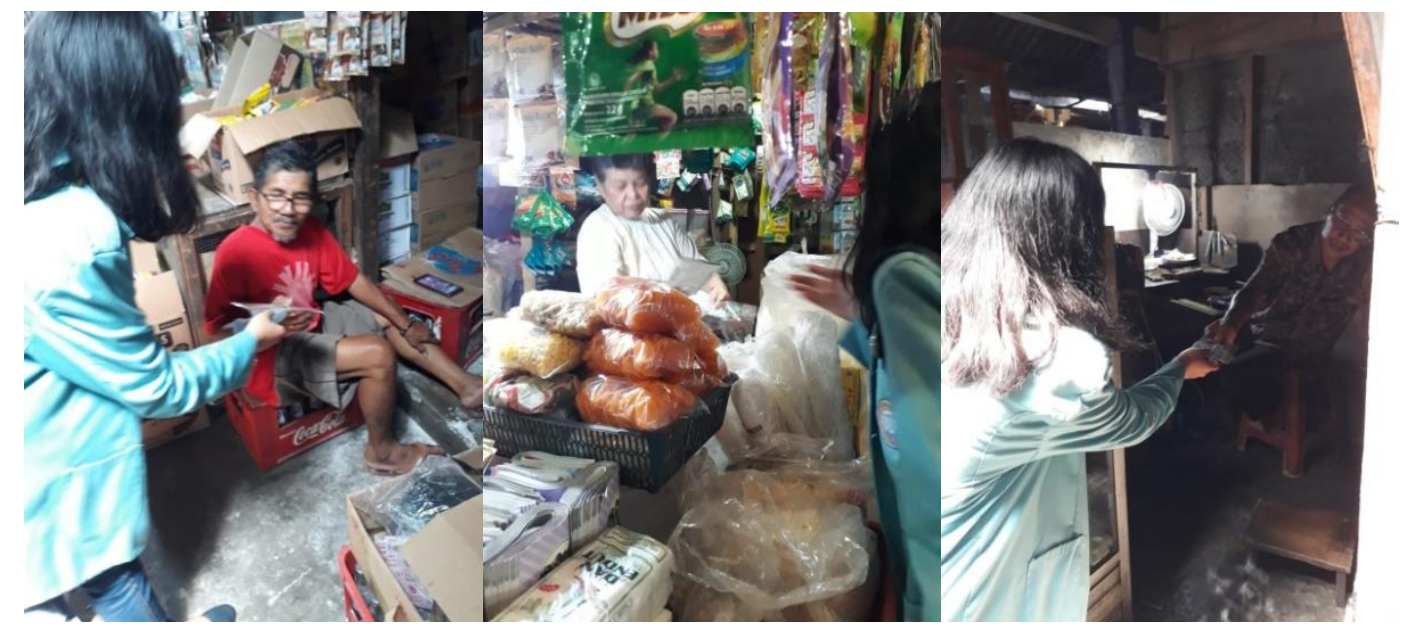

Gambar 6. Pendistribusian masker di pasar

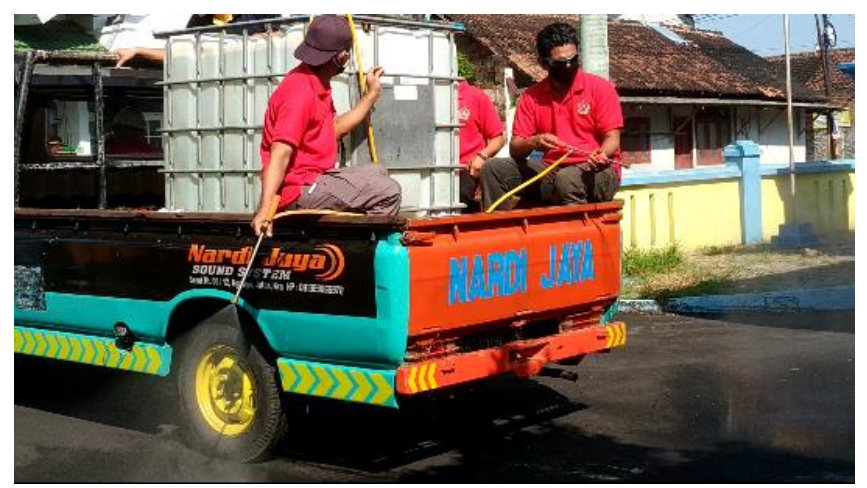

Gambar 7. Penyemprotan dan Edukasi COVID-19 sebanyak 8 dusun di Desa Ngringo

dengan edukasi memasuki new normal dan protokol kesehatan. Edukasi mengenai menggunakan masker katika keluar rumah, jaga jarak, menjaga kesehatan dan melakukan pola hidup bersih dan sehat (PHBS) dan tidak lupa untuk mencuci tangan setiap saat dengan menggunakan sabun dan air mengalir. Kegiatan ini bertujuan untuk memutus rantai penyebaran COVID-19 di Desa Ngringo serta mempersiapkan warga dalam memasuki new normal dengan menerapkan protokoler kesehatan. Melalui kegiatan ini warga desa ngringo menjadi paham mengenai ptotokol kesehatan karena kegiatan ini dilakukan dengan Mengelilingi seluruh rumah penduduk dan menggunakan pengeras suara dan memberikan himbauan agar warga yang sedang keluar rumah memakai masker.

\section{Ketahanan Pangan}

Pandemi yang disebabkan karena adanya virus corona Covid-19 ini membawa dampak yang luas bagi kehidupan masyarakat, karena tidak hanya menyebabkan permasalahan ekonomi tetapi juga berpotensi pada krisis kebutuhan pangan. Program ketahanan pangan dilakukan di dukuh Serut Desa Ngringo Kecamatan Jaten Kabupaten Karanganyar (Gambar 9, 10 dan 11). Tujuan dari program ketahanan pangan ini adalah agar tercukupinya kebutuhan pangan dan ketahanan pangan selama pandemi Covid-19 ini. Selain itu juga ada edukasi mengenai hidroponik dengan menggunakan botol bekas. Ketahanan pangan yang dibuat adalah ketahanan pangan berupa kebun sayuran yaitu sayuran sawi yang ditanam pada polybag dimana warga memenfaatkan pekarangan rumah untuk menanam tanaman sayur, ketahanan pangan berupa lele, ketahanan pangan berupa tanaman obat keluarga. Pemeliharaan ikan juga bisa dilakukan dengan system BUDIKDAMBER (budi daya ikan dalam ember) maupun di kolam (Febri et al., 2019). Ternak lele memanfaatkan sebidang tanah di sawah 
bengkok perangkat desa yang dikelola bersama dengan karang taruna sebagai ketahanan pangan lele ini dijual dengan harga yang lebih murah dari baisanya. Sehingga diharapkan dusun Serut Desa
Ngringo Kecamatan Jaten Kabupeten Karanganyar ini siap untuk menjadi dusun Siaga Covid-19 yang memiliki ketahanan pangan.
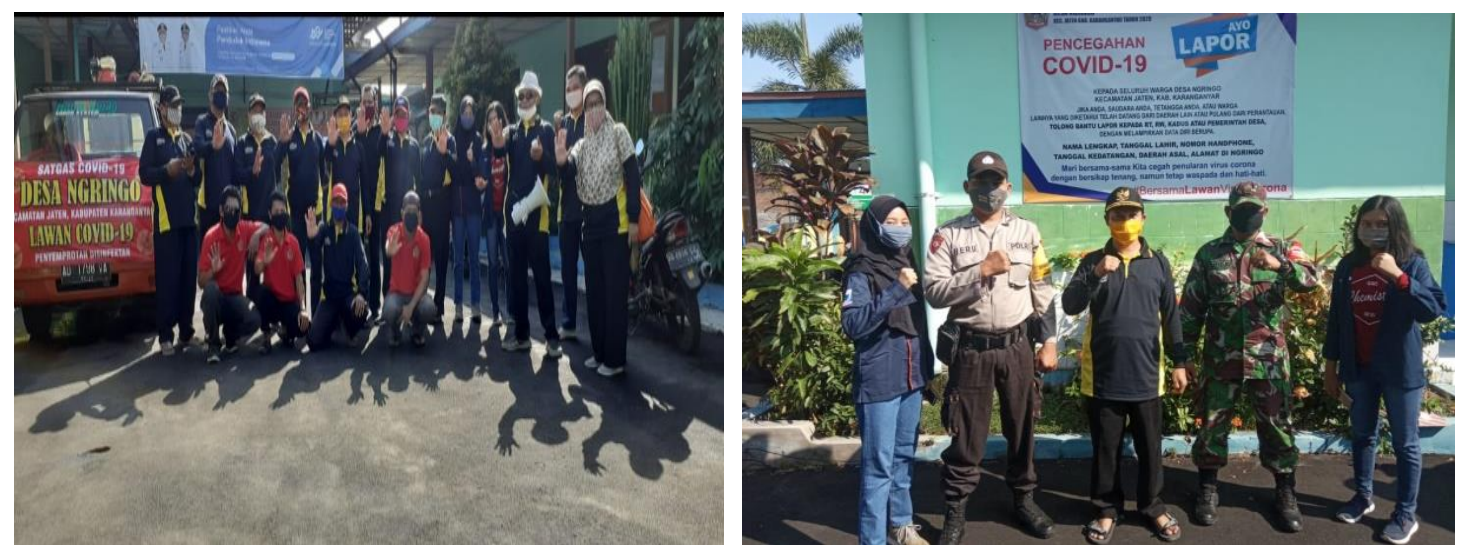

Gambar 8. Foto bersama dengan SATGAS Covid-19, Babinsa dan Bhabinkamtibmas
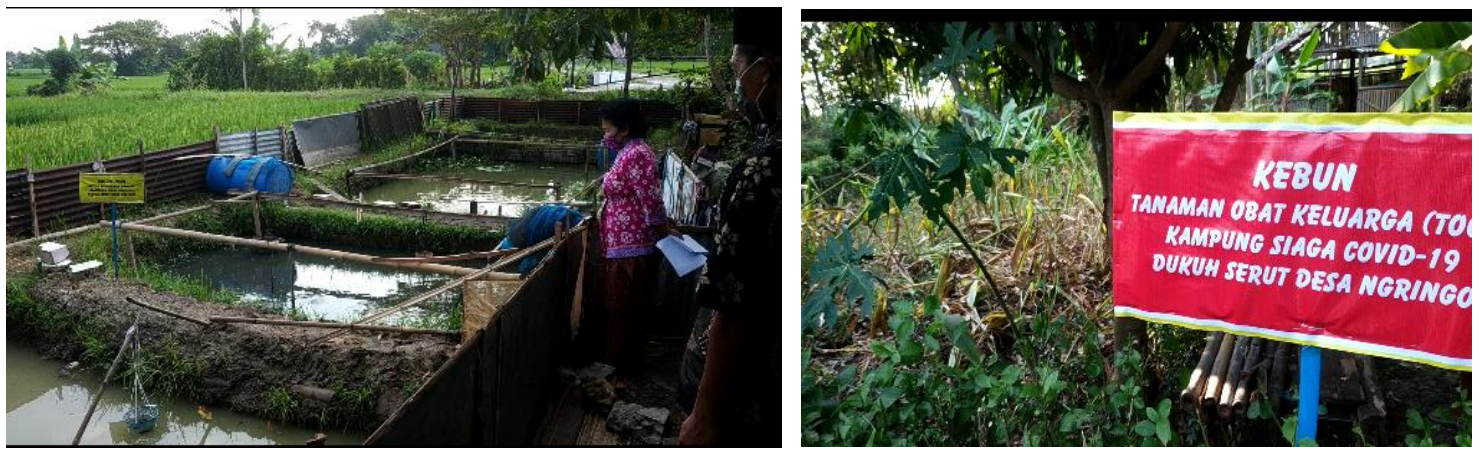

Gambar 9. Ketahanan pangan berupa kolam lele (kiri) dan kebun tanaman obat keluarga (kanan)
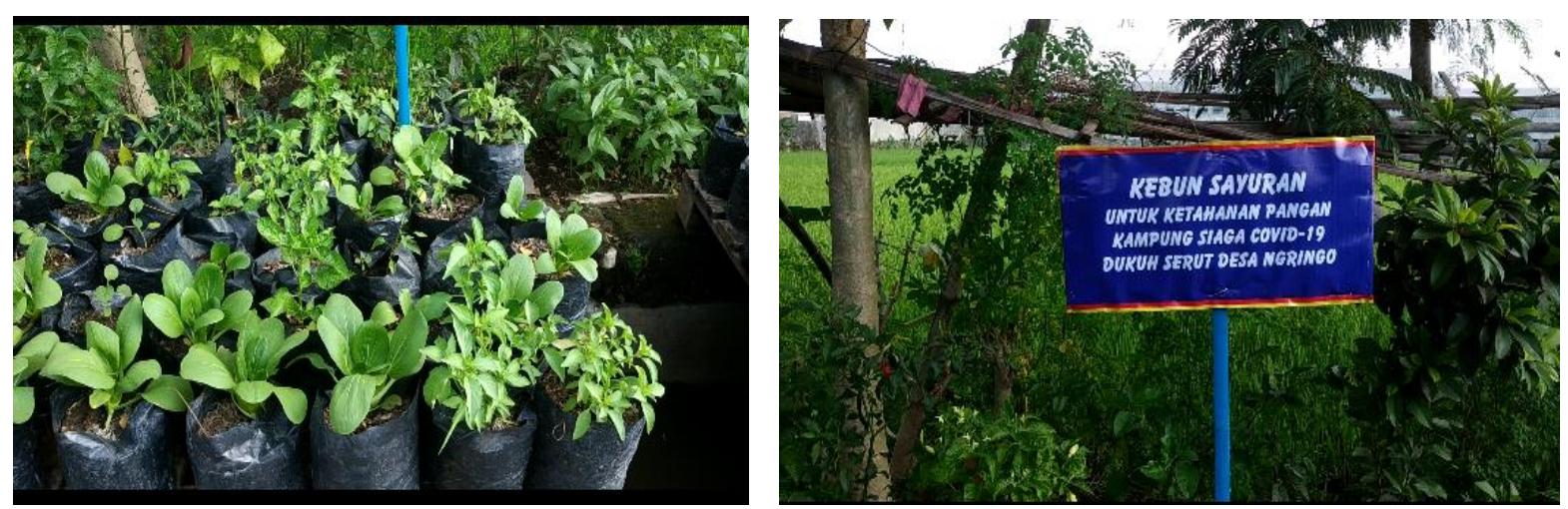

Gambar 10. Ketahanan pangan berupa warung hidup yaitu sayuran salah satunya adalah sawi dan cabai 


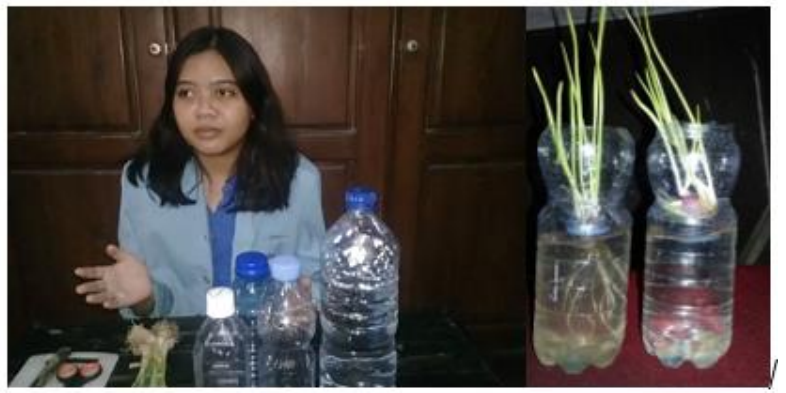

Gambar 11. Pembuatan Video tutorial

hidroponik dengan menggunakan botol bekas

\section{Chemistry Class}

Situasi pandemic Covid-19 menuntut dilakukannya pembelajaran secara daring menggunakan berbagai metode dan platform (Nurkholis, 2020). Metode belajar berubah dari sebelumnya menghabiskan waktu 6-8 jam di sekolah menjadi pembelajaran secara daring yang lebih bersifat individu, sehingga juga berdampak terhadap psikologi siswa, misalnya kejenuhan (Hakim, 2004; Nurkholis, 2020). Chemistry Class merupakan program kerja yang didasari dengan tuntutan kebutuhan pendidikan di masyarakat. Chemistry Class menggunakan konsep praktek bimbingan belajar yang dilakukan secara daring menggunakan media WhatsApp grup yang mengklasifikasikan anak-anak sesuai dengan kebutuhan dan tingkat satuan pendidikannya, sehingga mudah dalam proses pembelajarannya (Gambar 12).

Chemistry Class beranggotakan siswa SMA kelas 10 dan kelas 11 dari berbagai SMA Negeri di karisidenan Surakarta. Pelaksanaan program ini dilakukan dalam 1 grup yang sama dengan jadwal yang bergantian sesuai dengan kesepakatan. Untuk kegiatan pembelajaran online ini meliputi penyampaian materi dalam bentuk PDF dan pemberian soal, latihan soal dan pembahasan serta diskusi tanya jawab. Anak-anak sangat antusias di grup WA banyak pertanyaan yang diajukan, responsif karena pembelajaran kimia yang bersifat abstrak sehingga memerlukan pemahaman yang lebih agar bisa menerima pembelajaran. Pelayanan yang diberikan juga meliputi konsultasi individu melalui personal chat untuk adik-adik yang kesulitan terhadap tugas yang diberikan. Adanya program Chemistry Class membantu siswa menjadi lebih paham materi kimia.
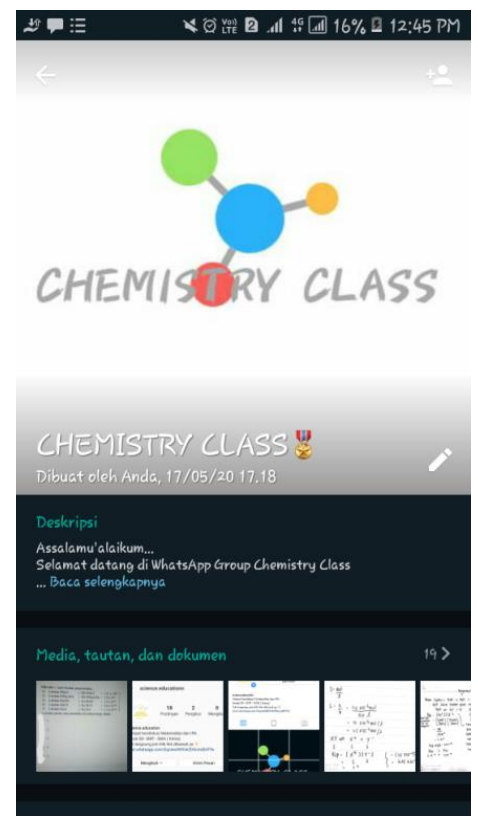

Gambar 12. Grup WA Chemistry Class yang terdiri dari 117 anggota

\section{Pendataan Pemudik}

Pendataan pemudik dilakukan bersama dengan tim SATGAS Covid-19 desa Ngringo Pendataan meliputi Nama, Alamat, Umur, Datang dari, No HP, keluhan dan tanggal datang. Pendataan bertujuan untuk mengetahui pendatang dan agar melakukan karantina secara mandiri di rumah masing-masing dan dilakukan pemantauan kesehatan serta keluhan (Gambar 13). Sampai dengan tanggal 24 Mei 2020 ada 106 warga yang melakukan pulang kampung dari luar negeri ataupun dari kota lain dalam negeri.

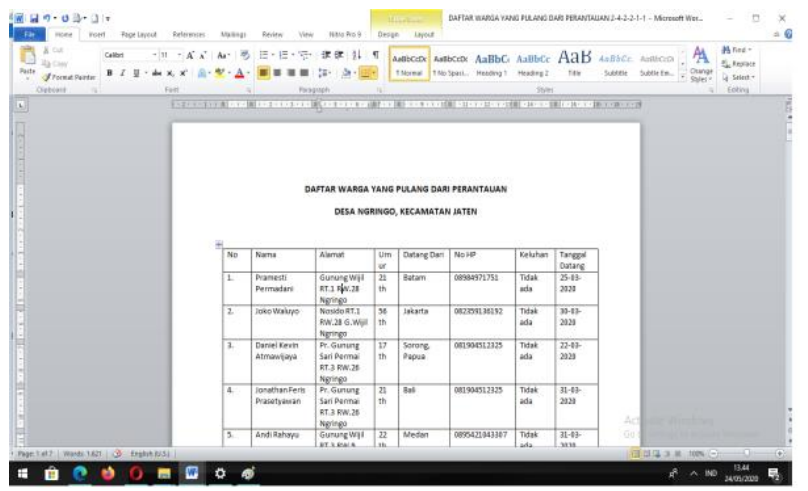

Gambar 13. Pendataan pemudik Desa Ngringo yang pulang dari perantauan sejak 25 Maret 2020 sampai dengan tanggal 24 Mei 2020

Kesehatan 


\section{Lomba Dusun Siaga Covid-19}

Penilaian lomba Kampung siaga Covid-19 oleh tim penilai dari Polres Karanganyar, Kodim, Dinas Kesehatan dan Dispermades Karanganyar di posko kampung siaga Covid-19 Dukuh Serut. Lomba diadakan pada tanggal 18 Juni 2020, dimana lomba ini merupakan kegiatan bersama dengan Bhabinkamtibmas Desa Ngringo, Babinsa, Kades beserta perangkat desa, BPD, lembaga desa serta tokoh masyarakat dalam rangka menghimbau protokoler kesehatan dan kemananan ketertiban masyarakat. Dimana Desa Serut RT 06 RW 12 ini merupakan perwakilan dari Kecamatan Jaten untuk lomba ditingkat Kabupaten Karanganyar. Persiapan dengan memastikan didepan rumah memiliki tempat untuk cuci tangan dan tim KKN menempel stiker tempat untuk cuci tangan dan kawasan wajib pakai masker (Gambar 14 dan 15). Hasil penilaian bahwa dari 86 Desa yang turut serta sebagai peserta, Dusun Serut masuk dalam 6 besar yang kemudian akan ditinjau langsung oleh Bupati Karanganyar.
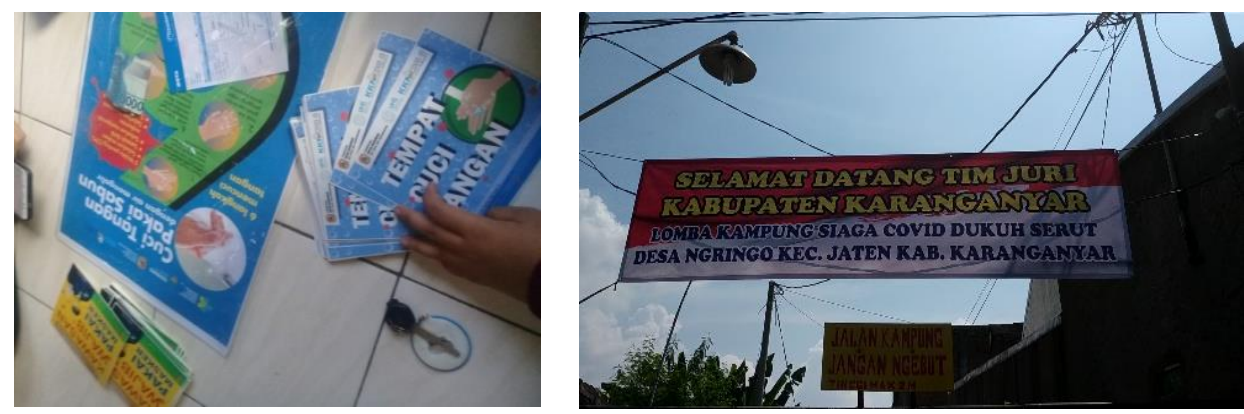

Gambar 14. Persiapan Lomba Dusun siaga COVID-19 dengan penempelan stiker tempat cuci tangan disekeliling desa Serut
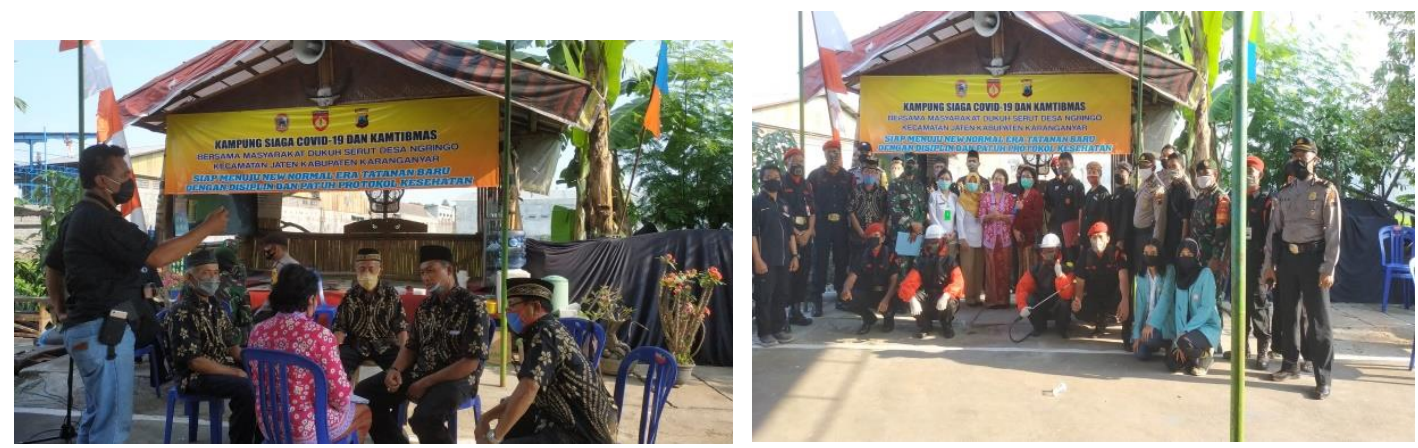

Gambar 15. Penilaian Desa Serut sebagai Desa Siaga Covid-19 tingkat kabupeten

\section{KESIMPULAN}

Kesimpulan yang diperoleh dari hasil kegiatan KKN ini adalah warga desa Ngringo khususnya dusun Serut RT 06/RW 12 sudah melaksanakan protokol keseahatan sesuai dengan anjuran pemerintah yaitu memakai masker ketika keluar rumah, jaga jarak, mencuci dengan langkah yang benar menggunakan sabun serta air mengalir melakukan pola hidup bersih dan sehat (PHBS). Warga mulai memahami apa itu Covid-19 dan berbagai informasi mengenai Covid-19. Warga merasa terbantu dengan adanya ketahanan pangan dusun Serut. Siswa yang sedang sekolah merasa terbantu dengan adnaya program kerja Chemistry Class. Adanya program KKN UNS Peduli Masyarakat terdampak Covid-19 di Desa Ngringo sangat membantu dan bermanfaat untuk masyarakat sekitar dalam masa pandemi ini.

\section{DAFTAR PUSTAKA}

Febri, S.P. Alham, F., Afriani, A. 2019. Pelatihan BUDIKDAMBER (Budidaya Ikan Dalam Ember) di Desa Tanah Terban Kecamatan Karang Baru Kabupaten Aceh Tamiang. Proceeding 
Seminar Nasional Politeknik Negeri Lhokseumawe, 3: C112-C117.

Hakim, T. 2004. Belajar Efektif. Puspa Swara. Jakarta.

Nurani, N.I., Uswatun, D.A., Maula, L.H. 2020. Analisis Proses Pembelajaran Matematika Berbasis Daring Menggunakan Aplikasi Google Classroom Pada Masa Pandemi Covid-19. Jurnal PGSD. 6(1): 50-56.

Nurkholis, 2020. Dampak Pandemi NovelCorona Virus Disiase (Covid-19) Terhadap Psikologi Dan Pendidikan Serta Kebijakan Pemerintah. Jurnal PGSD, 6(1): 39-49.

Susilo A., C.M. Rumende, C.W. Pitoyo, W.D. Santoso, M. Yulianti, H. Kurniawan, R.
Sinto, G. Singh, L. Nainggolan, E.J. Nelwan, L.K. Chen, A. Widhani, E. Wijaya, B. Wicaksana, M. Maksum, F. Annisa, C.OM Jasirwan, E. Yunihastuti. 2020. Coronavirus Disease 2019. Jurnal Penyakit Dalam Indonesia 7(1): 45-67.

Wulandari, A., Rahman, F., Pujianti, N., Sari, A.R., Laily, N., Angraini, L., Muddin, F.I., Ridwan, A.., Anhar, V.Y., Azmiyannoor, M., Prasetio, D.B. 2020. Hubungan Karakteristik Individu dengan Pengetahuan tentang Pencegahan Coronavirus Disease 2019 pada Masyarakat di Kalimantan Selatan. Jurnal Kesehatan Masyarakat Indonesia. 15: 42-46.

www.covid19.go.id. diakses pada tanggal 11 Mei 2020 pukul 12.30 WIB 